\title{
Dermatoglyphics in dentistry: a review
}

Dr. Sonali Kadam, Associate professor, Department of Oral Medicine \& Radiology, Government Dental College \& Hospital, Mumbai, India

Dr. Debpriya Biswas, Clinical Assistant, Government Dental College \& Hospital, Mumbai, India

Dr. Nimma Vijayalaxmi, Assistant professor, Department of Oral Medicine \& Radiology, Government Dental College \& Hospital, Mumbai, India

Dr. Bhagyashree Landge, PG Student, Department of Oral Medicine \& Radiology, Government Dental College \& Hospital, Mumbai, India

Citation: Kadam S, Biswas D, Vijaylaxami N, Landge B. Dermatoglyphics in dentistry: a review. Int J Eth Trauma Victimology 2019; 5(1):39-44. doi.org/10.18099/ijetv.v5i1.6.

\begin{tabular}{l|l} 
Article history & Fingerprint analysis for personal identification is well known and
\end{tabular}

Received: Jan 24, 2019

Received in revised form: May 19, 2018

Accepted: June 13, 2019

Available online: Nov 10, 2019

Corresponding author is unique to all individuals and remains the same for a lifetime. The hand has become a powerful tool in the diagnosis of psychological, medical, genetic conditions. Dentistry is no exception has number of diseases which can be diagnosed using the study of finger prints described as dermatoglyphics. The present review describes peculiar changes in dental diseases and

Dr. Sonali Kadam gives an insight to the supporting literature.

Associate professor, Department of Oral

Medicine \& Radiology, Government

Dental College \& Hospital, Mumbai, India

Phone: +919869022323

Email: sonalikdm863@gmail.com

Keywords: Dentistry; dermatoglyphics; oral diseases.

(C) IJETV. All rights reserved

\section{Introduction}

Derived from Greek words "Dermatoglyphics" comes from derma which means skin and glyphe which means carve and refers to the epidermal skin ridge formations which appear on the fingers, palms of the hand and soles of the feet (1). The term was coined by Harold Cummins in 1926 who is known as the "Father of Dermatoglyphics" (2). During the $6^{\text {th }}-7^{\text {th }}$ week of embryonic life finger and palm prints are formed and completed after 10-20 weeks of gestation (3). They are unique for each person and is not even same in monozygotic twins, studying them can determine a number of parameters helpful in the diagnosis and treatment of examined individuals (4). Anatomically the ridge patterns are influenced by the blood vessel nerve pairs at the border between dermis and epidermis during prenatal development. Affected by the factors such as inadequate oxygen supply, unusual distribution of sweat glands and alteration of epithelial growths. The ridge pattern is considered sensitive because it originates from the fetal volar pads just like the teeth which also develop from the ectoderm at the $6^{\text {th }}-7^{\text {th }}$ week of intrauterine life.
Dermatoglyphics are utilized for the purpose because of following reasons (i) once fully developed and remain unchanged for life. (ii) Easy scanning and recording, rapid, inexpensive, and convenient without causing any trauma to the patient or hospitalization.

\section{Methods of recording}

The various methods that are employed are:

Ink method: The advantages of this method is that it is economical, easy technique, convenient. Disadvantages include improper prints, cannot be used in case of gross malformation of limbs.

Inkless method: This technique makes use of a commercially available patented solution and specially treated sensitized paper.

Transparent adhesive tape method: This technique involves using transparent adhesive tapes to obtain fingerprint patterns

Photographic method: This technique involves use of photographs.

Dermatoglyphic pattern configuration:

The three basic dermatoglyphic landmarks found are triradii, cores and radiants. 
Triradii: Formed by confluence of 3 ridges which meet at 120 degrees.

Core: Approximate center of the pattern

Radiant: Emanate from triradii and enclose the pattern area.

Fingerprint patterns: There are 3 groups: Arches, loops, whorls.

Arches: It is the simplest pattern. It is formed by succession of more or less parallel ridges which traverse the pattern area and form a curve which is concave proximally. Sometimes curve is gentle, it may swing more sharply and can be a low or high arch. These are of 2 types:

Simple arch

Tented arch

Loops: Most common pattern. A series of ridges enter the pattern area on one side of the digit, recurve abruptly, and leave the pattern on the same side. These are of 2 types:

Ulnar loop: loops open on the ulnar side.

Radial loop: loops open on the radial side.

Whorls: Ridge pattern with 2 or more triradii. One is radial and the other 2 are ulnar. These are of the following types:

Plain: Arranged in form of concentric rings or ellipses.

Table 1: Dermatoglyphics in various dental diseases

Author Study

Zarakauskite et.al (5) Case control study

Scott et al (6)

Matthew et al (7)

Balgir et al (8)
Saxena et al (9)
460 Non syndromic cleft lip and palate patients and 254 unaffected relatives from Philippines and China were studied

Dermatoglyphic patterns of 100 children between 5-15 years of which 50 consisted of study group and 50 controls

Dermatoglyphic patterns of 69 cases of cleft lip and palate and 28 isolated cleft palate cases were studied.

Studied dermatoglyphic patterns of 294 subjects
Spiral: Spirals in clockwise or anticlockwise direction

Central Pocket: Loop within loop type of pattern

Lateral Pocket: Interlocking loops

Accidental: Cannot be classified.

Palmar patterns:

The palm is divided anatomically into thenar, second, third and fourth interdigital areas and the hypothenar area.

Thenar and First interdigital area: These two are closely related anatomically and are considered one area.

Second, third and fourth interdigital area: Configurations seen are loops, whorls, vestiges and open fields.

Hypothenar area: Patterns seen are whorls, loops, tented arches.

\section{Use of dermatoglyphics in dentistry}

Recently recognition of changes in fingerprints among patients with various dental ailments like periodontitis, dental caries and certain types of congenital anomalies like cleft lip and palate has drawn attention of researchers in the field of dermatoglyphics and further encouraged them in knowing the role of dermatoglyphics in various dental diseases.

Studied dermatoglyphic patterns
of 294 subjects




\section{Cleft Lip and Palate}

Cleft lip and palate cause's problems in speech, feeding, hearing and may cause frequent ear infections. Different fingerprint patterns determine the predisposition of cleft lip and palate.

\section{Dental Caries}

Dental caries is one of the most common oral health diseases which affect millions of people worldwide. Dermatoglyphics can help determine the susceptibility to dental caries.

Table 2: Different studies for Dental Caries

\begin{tabular}{lll}
\hline Author & \multicolumn{1}{c}{ Studies } & Observation \\
\hline Atasu et al (10) & $\begin{array}{l}\text { Studied dermatoglyphic patterns in } \\
\text { caries free students and students } \\
\text { with extensive caries }\end{array}$ & $\begin{array}{l}\text { Caries free students had } \\
\text { more ulnar loops and } \\
\text { students with extensive } \\
\text { caries had more whorls. }\end{array}$ \\
Sharma et al (11) & $\begin{array}{l}90 \text { subjects were evaluated to } \\
\text { determine the relation between } \\
\text { salivary bacteria interactions, } \\
\text { dental caries and dermatoglyphics. }\end{array}$ & $\begin{array}{l}\text { Subject groups had } \\
\text { positive correlation with } \\
\text { loops and Streptococcus } \\
\text { mutans growth and } \\
\text { likened to control group } \\
\text { wadma et al (12) }\end{array}$ \\
& $\begin{array}{l}\text { Studied caries and dermatoglyphic nad negative } \\
\text { peculiarities in deaf and mute } \\
\text { children }\end{array}$ & $\begin{array}{l}\text { correlation of both. } \\
\text { Increase in whorl patterns } \\
\text { in study groups and } \\
\text { increase in loops in }\end{array}$ \\
\end{tabular}

Periodontal disease leads to loss of tooth and

Periodontal Disease abscess. Dermatoglyphics patterns can help determine the incidence of periodontal disease.

Table 3: Studies of Periodontal diseases and pattern of fingerprints

\begin{tabular}{|c|c|c|}
\hline Author & Studies & Observation \\
\hline Atasu et al (13) & $\begin{array}{l}\text { Conducted study with aim of } \\
\text { finding fingertip pattern type } \\
\text { to help identify patients with } \\
\text { periodontal disease }\end{array}$ & $\begin{array}{l}\text { - Decreased frequencies of twinned } \\
\text { and transversal ulnar loops on all } \\
\text { fingers of patients with juvenile } \\
\text { periodontitis } \\
\text { - Decreased frequencies of double } \\
\text { loops on all fingers } \\
\text { - Increased frequencies of radial } \\
\text { loops on the right second digit of } \\
\text { patients with rapidly progressive } \\
\text { periodontitis } \\
\text { Increased frequency of concentric } \\
\text { whorls and transversal ulnar loops } \\
\text { on all the fingers of patients with } \\
\text { adult periodontitis. } \\
\text { Increased frequency of triradii on } \\
\text { palms and soles of patients with } \\
\text { juvenile periodontitis was found. }\end{array}$ \\
\hline \multicolumn{3}{|c|}{$\begin{array}{l}\text { worldwide and is seen most commonly in Asian } \\
\text { countries. Dermatoglyphic patterns help } \\
\text { determine the genetic predisposition to such } \\
\text { carcinomas and potentially malignant diseases. }\end{array}$} \\
\hline
\end{tabular}


Table 4: Dermatoglyphics of Gutka chewers

\begin{tabular}{|c|c|c|}
\hline Author & Studies & Observation \\
\hline Tamgire et al (14) & $\begin{array}{l}\text { Carried out prospective study } \\
\text { by collecting dermatoglyphic } \\
\text { prints of gutka chewers with } \\
\text { or without osmf. } 200 \text { subjects } \\
\text { divided into } 2 \text { groups. Group A } \\
\text {-100 gutka chewers without } \\
\text { osmf .Group B-100 gutka } \\
\text { chewers with osmf. }\end{array}$ & $\begin{array}{l}\text { - Highly significant decrease in } \\
\text { simple whorl pattern and increase } \\
\text { in composite whorl pattern on left } \\
\text { little finger in Group B as } \\
\text { compared to Group A. } \\
\text { - Decrease in composite whorl } \\
\text { pattern of right index finger in } \\
\text { Group B compared to Group A, } \\
\text { increase in simple whorl pattern } \\
\text { on right thumb in Group B when } \\
\text { compared with Group A } \\
\text { Decrease in radial loop on left } \\
\text { index finger in Group B when } \\
\text { compared to Group A. }\end{array}$ \\
\hline Elluru Venkatesh (15) & $\begin{array}{l}\text { Carried out study to determine } \\
\text { whether specific } \\
\text { dermatoglyphic patterns exist } \\
\text { which help in predicting the } \\
\text { occurrence of oral squamous } \\
\text { cell carcinoma and oral } \\
\text { leukoplakia.30 subjects were } \\
\text { studied with oscc,30 with } \\
\text { leukoplakia and } 30 \text { as controls }\end{array}$ & $\begin{array}{l}\text { - Arches and loops more common in } \\
\text { cases than in controls. Whorls } \\
\text { more common in controls. } \\
\text { - Loops more frequent in } \\
\text { interdigital areas than in controls } \\
\text { No correlation between atd angle } \\
\text { ab ridge count and total ridge } \\
\text { count in oral squamous cell } \\
\text { carcinoma and leukoplakia. }\end{array}$ \\
\hline
\end{tabular}

\section{Malocclusion}

Most common orthodontic problem suffered by millions worldwide is malocclusion. Malocclusion hampers speech, esthetics, swallowing and may cause dental caries and periodontal disease due to disharmony between teeth, bone and soft tissues. Dermatoglyphics helps in determining the genetic predisposition of certain malocclusions.

Table 5: Dermatoglyphic studies of Malocclusion

\begin{tabular}{|c|c|c|}
\hline Author & Studies & Observation \\
\hline Reddy et al (16) & $\begin{array}{l}\text { Conducted dermtatoglyphic } \\
\text { study to compare class I,II,III, } \\
\text { malocclusions.96 subjects } \\
\text { divided into } 3 \text { groups: Class I - } \\
\text { control ,Class II div 1,2 and class } \\
\text { III -experimental group .Age } \\
\text { group-12-14 years }\end{array}$ & $\begin{array}{l}\text { - Class II div } 2 \text { showed increased } \\
\text { frequency of arches and ulnar } \\
\text { loops and decreased frequency } \\
\text { of whorls. } \\
\text { - Class III showed increased } \\
\text { frequency of arches and radial } \\
\text { loops and decreased frequency } \\
\text { of ulnar loops. } \\
\text { - Sensitivity values of Class III } \\
\text { more than Class II div } 1 \text { and } 2 \text {. }\end{array}$ \\
\hline Tikare et al (17) & $\begin{array}{l}\text { Conducted study to assess the } \\
\text { relationship between } \\
\text { dermatoglyphics and } \\
\text { malocclusion among high } \\
\text { school children.696 high school } \\
\text { children aged 12-14 years were } \\
\text { randomly selected. }\end{array}$ & $\begin{array}{l}\text { - Statistical association between } \\
\text { whorl patterns and Class I and } \\
\text { Class II malocclusion was found. }\end{array}$ \\
\hline Bruxism & \multicolumn{2}{|c|}{$\begin{array}{l}\begin{array}{l}\text { Bruxism leads to attrition of teeth and soreness of } \\
\text { muscles of mastication. Certain dermatoglyphics } \\
\text { patterns help determine incidence of bruxism. }\end{array} \\
\text { Int J Eth Trauma Victimology 2019; 5(1):42. }\end{array}$} \\
\hline
\end{tabular}


Table 6: Dermatoglyphic studies in Bruxism

\begin{tabular}{llr}
\hline Author & \multicolumn{1}{c}{ Studies } & Observation \\
\hline Polat et al (18) & $\begin{array}{l}\text { Examined } \\
\text { patterns of } 38 \text { patients of which } 18 \\
\text { were females. }\end{array}$ & $\begin{array}{l}\text { Increase in whorls, I loops, } \\
\text { and triradii. } \\
\text { Decrease in frequency of } \\
\text { ulnar loops, atd angle, } \\
\text { triradii than the controls. }\end{array}$ \\
Oral Tumors & $\begin{array}{l}\text { Oral tumors include odontogenic and non- } \\
\text { odontogenic tumors and dermatoglyphic patterns } \\
\text { help determine the incidence of such tumors. }\end{array}$
\end{tabular}

Table 7: Studies with oral tumors

\begin{tabular}{llll}
\hline Author & Studies & Observations \\
\hline Polat et al (19) & $\begin{array}{l}\text { Investigated } \\
\text { patterns of patients with or without patterns. } \\
\text { tumors }\end{array}$ & \\
\hline
\end{tabular}

Dental Arch Forms

Dental arch forms are very important in orthodontics and prosthodontics. In orthodontic treatment it is very important for diagnosis and

Table 8: studies of Dermatoglyphics relationship with arch forms

\begin{tabular}{llll}
\hline Author & \multicolumn{1}{c}{ Studies } & Observation \\
\hline Sachdeva et al (20) & $\begin{array}{l}\text { Studied to identify relation } \\
\text { between dermatoglyphics and } \\
\text { arch forms. } 90 \text { subjects were } \\
\text { divided into } 3 \text { groups -square, } \\
\text { tapering, ovoid. }\end{array}$ & $\begin{array}{l}\text { Subjects with square arch } \\
\text { had high frequency of } \\
\text { loops and large atd angle } \\
\text { Subjects with tapering } \\
\text { arches showed high } \\
\text { frequency of whorls and } \\
\text { small atd angle. } \\
\end{array}$ \\
& & Ovoid arch subjects had \\
loops.
\end{tabular}

\section{limitations}

- Difficult to use as a diagnostic tool if patient has gross malformation of limbs

- Atd angle can have several disadvantages regarding its use as a parameter. One shortcoming is the size of atd angle that is affected by the amount of spreading of the fingers when the patterns are recorded. Pressure exerted also affect atd angle.

- A thick or thin application of ink can result in light or dark improper prints.

\section{Conclusion}

Dermatoglyphics is an upcoming integral part of medicine and forensic science. The correlation of dermatoglyphics with dental abnormalities is still in its nascent stage and presently it is safe to say that various finger print patterns can be treatment planning and to preserve it throughout the treatment to achieve a higher stability. In prosthodontic treatment it determines the treatment of edentulous and partial edentulism. considered as an indicator for occurrence of congenital abnormalities. Dermatoglyphics has moved from obscurity to acceptability as a diagnostic tool. It may serve as an important tool that can predict the future health of a person.

\section{Conflict of Interest}

None declared

\section{References}

1. Sharma A, Kapoor D. Dermatoglyphics, dentistry and diagnosis-A review. Baba Farid Univ Dent J. 2010;1(2):45-48.

2. Bhat GM, Mukhdoomi MA, Shah BA, Ittoo MS. Dermatoglyphics: in health and disease-a review. Int J Res Med Sci. 2014;2(1):31-37.

3. Sharma R, Sharma R. Anthropology. Atlantic Publishers \& Dist.; 1997. 90 p. 
4. Ahmed $\mathrm{RH}$, Aref $\mathrm{MI}$, Hassan RM, Mohammed NR. Dermatoglyphic study on patients with dental caries who wearing dental fillings and its correlation to apoptosis that induced by using dental fillings. Nat Sci. 2010;8:54-7.

5. Zarakauskaitė E, Matulevičienè A, Utkus A, Kučinskas V, Linkevičienè L. Orofacial clefts with associated anomalies in Lithuania. Acta Medica Litu. 2007;17-23.

6. Scott NM, Weinberg SM, Neiswanger K, Brandon CA, Daack-Hirsch S, Murray JC, et al. Dermatoglyphic fingerprint heterogeneity among individuals with nonsyndromic cleft lip with or without cleft palate and their unaffected relatives in China and the Philippines. Hum Biol. 2005;77(2):257-266.

7. Mathew L, Hegde AM, Rai K. Dermatoglyphic peculiarities in children with oral clefts. J Indian Soc Pedod Prev Dent. 2005;23(4):179.

8. Balgir RS. Dermatoglyphics in cleft lip and cleft palate anomalies. Indian Pediatr. 1993;30(3):341-346.

9. Saxena RS, David MP, Indira AP. Dermatoglyphic evaluation in subjects and parents of cleft lip with and without cleft palate. Cleft Palate Craniofac J. 2013;50(6):105-110.

10. Atasu M. Dermatoglyphic findings in dental caries: a preliminary report. J Clin Pediatr Dent. 1998;22(2):147-149.

11. Sharma A, Somani R. Dermatoglyphic interpretation of dental caries and its correlation to salivary bacteria interactions: An in vivo study. J Indian Soc Pedod Prev Dent. 2009;27(1):17.

12. Bhat PK, Badiyani BK, Chengappa $\mathrm{S}$, Bhaskar NN. Dermatoglyphics-A new diagnostic tool in detection of dental caries among deaf and mute children. Int J Clin Dent Sci. 2012;2(4).

13. Atasu $M$, Kuru B, Firatli E, Meriç $H$. Dermatoglyphic findings in periodontal diseases. Int J Anthropol. 2005;20(1-2):6375.

14. Vk C, Ss R, Ar S. Qualitative dermatoglyphic analysis of finger tip patterns in patients of oral sub mucous fibrosis. IOSR J Dent Med Sci IOSR-JDMS E-ISSN. 2013;2279-0853.

15. Venkatesh E. Palmar dermatoglyphics in oral leukoplanka and oral squamous cell carcinoma patients [PhD Thesis]. RGUHS; 2006.

16. Reddy S, Prabhakar AR, Reddy VV. A dermatoglyphic predictive and comparative study of Class I, Class II, div. 1, div. 2 and Class III malocclusions. J Indian Soc Pedod Prev Dent. 1997;15(1):13-19.

17. Tikare S, Rajesh G, Prasad KVV, Thippeswamy V, Javali SB. Dermatoglyphics-A marker for malocclusion? Int Dent J. 2010;60(4):300304.

18. Polat $\mathrm{MH}$, Azak A, Evlioglu G, Malkondu OK, Atasu M. The relation of bruxism and dermatoglyphics. J Clin Pediatr Dent. 2000;24(3):191-194.

19. Polat $\mathrm{MH}$, Gululmser $\mathrm{P}$, Banu $\mathrm{K}$. Dermatoglyphic findings in patients with oral cancers. Balk J Stomatol. 2004;8:105108.

20. Sachdeva S, Tripathi A, Kapoor P. Dermatoglyphic assessment in subjects with different dental arch forms: an appraisal. J Indian Prosthodont Soc. 2014;14(3):281-288. 